\title{
An Evaluation of Silage Widely Use in Animal Feeding in Terms of Legislation in Turkey and European Union
}

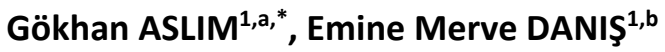 \\ ${ }^{1}$ Selçuk Üniversitesi, Veteriner Fakültesi, Veteriner Hekimliği Tarihi ve Deontoloji AD, Konya, Türkiye. \\ ${ }^{\mathrm{a} O R C I D ~ I D ; 0000-0001-5976-8186, ~ ' ~ O R C I D ~ I D ; ~ 0000-0003-0296-4391 ~}$
}

Geliş Tarihi: 08.06.2021

Kabul Tarihi: 09.10.2021

\begin{abstract}
Silage is a source of roughage obtained by anaerobic fermentation of fresh green feeds, certain vegetable products, and agricultural and industrial waste. Silage is widely used to feed animals and is importance for animals, humans, and the environment. This study, it was aimed to examine the production, use, and importance of silage, which is widely used in animal nutrition, in terms of legislation. Therefore, the study analyzed national and European Union legislation on the subject. For this purpose, content analysis was carried out on the relevant Turkey and European Union legislation. The scans determined that seven national and four European Union regulations could be related to issues animal feeding and silage. Therefore, it can be said that the issues related to silage management, including the precautions from production to consumption, should be defined in a way that minimizes the detrimental effects on animal, human and environmental health. Accordingly, specific regulations should be made on silage.
\end{abstract}

Keywords: Animal feeding, Legislation, Silage.

\section{Hayvan Beslemede Yaygın Olarak Kullanılan Silaj Yeminin Avrupa Birliği ve Türkiye'de Mevzuat Açısından Değerlendirilmesi}

Özet: Silaj; taze yeşil yemler, diğer bazı bitkisel ürünler ile tarımsal ve endüstriyel artıkların oksijensiz ortamlarda fermantasyonu ile elde edilen kaba yem kaynağıdır. Silaj, hayvan beslemede yaygın olarak kullanılmakta, hayvan, insan ve çevre açısından önem taşımaktadır. Çalışmada hayvan beslemede yaygın olarak kullanılan silajın üretimi, kullanımı ve öneminin mevzuat açısından incelenmesi amaçlandı. Bu amaçla konuyla ilgili Türkiye ve Avrupa Birliği mevzuatına içerik analizi yapıldı. Yapılan taramalarda hayvan besleme ve silaj konusu ile ilgili olabilecek yedi ulusal ve dört Avrupa Birliği düzenlemesi olduğu belirlendi. Üretimden tüketime kadar olan önlemler de dahil olmak üzere silaj yönetimi ile ilgili hususların hayvan, insan ve çevre sağlığı üzerindeki zararlı etkilerini en aza indirecek şekilde tanımlanması ve bu doğrultuda silaj konusunda spesifik düzenlemeler yapılması gerektiği söylenebilir.

Anahtar Kelimeler: Hayvan besleme, Mevzuat, Silaj.

\section{Introduction}

The livestock industry, which grows with the increasing world population (Eleroğlu et al., 2012; Tırınk, 2021), brings critical environmental problems in both developed and developing countries (Eleroğlu et al., 2012). As in all economic activities, agriculture and livestock also create significant pressure on the environment, as it is based on existing natural resources and the use of these resources (Dişbudak, 2008; Peypazar and Kılıç, 2021). The imbalances that occur while trying to increase the yield by forcing the plant, then the animal, starting from the soil, are directly reflected on the human being. Though it is late, it is understood that the findings, which increase income and productivity, have drawbacks that cannot be underestimated. Even if the attempts made to achieve economically favorable results by increasing the yield seem successful in the short term, it is seen that they cause various problems after a while (Koçtürk, 1975).

Animal nutrition involves providing the feed required by animals economically (Görgülü, 2002). Silage is an animal feed that has been pretty widely used in recent years due to its economic benefits in animal feeding (Çakmak et al., 2013; Yaylak and Alçiçek 2003). Presently, silage is a highly preferred feed component in animal feeding. Silage is obtained by compacting and storing fresh fodder materials under the influence of certain specific bacteria under anaerobic conditions. Thus, silage encompasses all kinds of plants and forage crops eaten by animals. It is processed and broken down under anaerobic conditions while retaining its nutritional value or even increasing it. It is stored for use during seasons when green feed is unavailable (Şahin and Zaman, 2010). 
It is believed that the preservation of feeds in silo form dates to ancient history. The first green forage silage was believed to be made by peasants in Italy in $700 \mathrm{AD}$. It is reported that silage production started in other European countries in the 18th century. The first studies on silage were performed in 1862 in Germany, in 1877 in France, and 1883 in the USA. In Turkey, the first silage was made in the Atatürk Forest Farm in 1931. It was initially produced only in state farms until 1975, after which silage production spread across the country (Şahin and Zaman, 2010; Uygur, 2005).

In several parts of the world, silage is an essential component of ruminant feeding when fresh crops are unavailable. Overall, given the excellent management and improved equipment available today, silage offers the best possibilities to maximize and maintain the nutritional value of a particular product from harvest to feeding (Pahlow et al., 2003). Economically, silage is cheaper than other feeds, with lower warehouse costs (Özhan, 2010) and labor requirements (Şahin and Zaman, 2010). Despite these advantages (Özhan, 2010; Şahin and Zaman, 2010), both microbial (e.g., Clostridium botulinum, Bacillus cereus, Listeria monocytogenes, and Escherichia coli) and chemical hazards (nitric oxide and nitrogen dioxide) may be associated with silage (Driehuis et al., 2018), which can exert harmful effects on human, animal, and environmental health (Peterson et al., 1958). In this direction, the solve the problems that silage can cause also becomes very important.

In parallel with the increase in the scope and intensity of environmental problems, economic and political ones are also increasing. However, the search for solutions to problems is intensifying (Ünder, 1996). The environmental issue is a significant issue within the scope of European Union (EU) policies. It is seen that agriculture and livestock activities are trying to be integrated with the protection of the environment (Dişbudak, 2008). Implementing the legislation in force in livestock enterprises and inspecting these practices will also be very beneficial in reducing the problems that may arise in terms of animals, humans, and the environment (Boyacl et al., 2011).

Therefore, this study evaluated the effects of silage usage, which presently represents a significant part in animal feeding management on animal, human, and environmental health, emphasizing the legislative aspects.

\section{Materials and Methods}

This study analyzed the Turkey (Law, Regulations, and Notices) and European Union (EU) legal regulations (Regulations, Directives, and Rules) regarding silage feed. By analyzing the content of the relevant legislative texts, the legal framework related to silage was determined.

In this study, the "document analysis method" was used from the available qualitative data analysis methods (Yıldırım and Şimşek, 2013).

The legal framework related to "silage feed" was determined by "content analysis" of the relevant legislative texts on the subject. The obtained data were evaluated within the scope of the legislative.

No ethical information is required for this study.

\section{Results}

It was determined that seven legal regulations related to animal feeding and silage feed in Turkey (Table 1 ) and four legal regulations (Table 2 ) in the EU.

Table 1. National regulations published on silage.

\begin{tabular}{clc}
\hline Institution & \multicolumn{1}{c}{ Regulations } & Official Gazette Date \\
\hline & Veterinary Services, Plant Health, Food, and Feed Law & $13 / 6 / 2010$ \\
& Regulation on Official Controls of Food and Feed & $17 / 12 / 2011$ \\
Ministry of & Regulation on Feed Hygiene & $27 / 12 / 2011$ \\
Agriculture and & $\begin{array}{l}\text { Regulation Regarding the Use of Feed Additives Substances } \\
\text { in Animal Nutrition }\end{array}$ & $18 / 7 / 2013$ \\
& $\begin{array}{l}\text { Notice on Unwanted Substances in Feeds } \\
\text { Regulation on the Sampling and Analysis Methods for } \\
\text { Official Control of Feeds }\end{array}$ & $19 / 4 / 2014$ \\
$\begin{array}{l}\text { Ministry of } \\
\text { Environment and } \\
\text { Urbanisation }\end{array}$ & Waste Management Regulation & $21 / 1 / 2017$ \\
\end{tabular}


Table 2. EU regulations on silage.

\begin{tabular}{lcc}
\hline \multicolumn{1}{c}{ Regulations } & Numbered & Dated \\
\hline $\begin{array}{l}\text { Regulation (EC) of the European Parliament and of the Council on } \\
\text { Additives for Use in Animal Nutrition }\end{array}$ & $1831 / 2003$ & $22 / 9 / 2003$ \\
$\begin{array}{l}\text { Commission Regulation (EC) Laying Down the Methods of Sampling and } \\
\text { Analysis for the Official Control of Feed }\end{array}$ & $152 / 2009$ & $27 / 1 / 2009$ \\
$\begin{array}{l}\text { Commission Directive amending Annex I to Directive 2002/32/EC of the } \\
\text { European Parliament and of the Council as regards mercury, free } \\
\text { gossypol, nitrites and Mowrah, Bassia, Madhuca }\end{array}$ & $2010 / 6$ & $10 / 2 / 2010$ \\
$\begin{array}{l}\text { Commission Implementing Regulation (EU) Concerning the Authorisation } \\
\text { of Sodium Benzoate, Potassium Sorbate, Formic Acid and Sodium Formate } \\
\text { as Feed Additives for All Animal Species }\end{array}$ & $2016 / 2023$ & $18 / 11 / 2016$ \\
\hline
\end{tabular}

Turkey's accession process to the EU, an outstanding act with No. 5996 "Veterinary Services, Plant Health, Food, and Feed Law" was adopted by the Turkish Government regarding food, agriculture, and animal husbandry. One statement of this act was on protecting and ensuring feed safety, public health, animal health, and environmental health. In another article of the above act, it was described that "To ensure the enforcement of this Law, the Ministry conducts official controls on all stages of production, processing, and distribution of food and feed operators, and keeps records on food and feed businesses" (Official Gazette, 2010).

The Annex-2 of Law No. 5996 states that the control officers who carry out the official controls of the feed establishments are veterinarians, agricultural engineers, and aquaculture engineers (Official Gazette, 2010). However, there are secondary legislative texts on feeds based on Law No. 5996. One of these legislative texts is on the "Regulation on Official Controls of Food and Feed." The fifth article states that the control officer carries out the "Official checks of feed establishments" within the regulation under the list of Annex-2 included in the Annex of the Law. In official controls, technicians, operators, and assistant health personnel who are trained in related professions can also be assigned to assist the control officer." As far as the entire regulation is concerned, there is no article on the control of silage (Official Gazette, 2011a).

The "Regulation on the Sampling and Analysis Methods for Official Control of Feeds," prepared based on the "Commission Regulation" (European Commission, 2009) numbered EC 152/2009, was published in the Official Gazette on January 21, 2017, and implemented since then. It was determined in the annexes of the regulation that the works and procedures to be conducted on the samples to be taken from the feeds were included. However, the specific analyses for microbial and chemical hazards that may occur in the silage were not included (Official Gazette, 2017). The "2020 Analysis List" of the Ministry of Agriculture and Forestry Central Research Institute of Food and Feed Control recommended that the "pesticide analysis" should be carried out "for silage feeds" (MAF, 2019). Also, it was recommended by the Directorate of the International Center for Livestock Research and Training affiliated to the Ministry that "Silage Acids" and "Corn Silage Energy Value Calculation" analyses should be conducted on silage (MAF, 2020).

In the "Notice on Unwanted Substances in Feeds" Annex-1, which was prepared in line with the rates set in the EU Commission Directive numbered 2010/6/EU (European Commission, 2010) and published in the Official Gazette on April 19, 2014, the acceptable rates of unwanted substances in feeds were determined. It was stated that nitrites should not be present in silage according to the food containing $12 \%$ moisture. In other regulations, no other rate is specified for other microbial and/or chemical hazards that may occur in the silage (Official Gazette, 2014).

The regulations of the EU on additives used in animal nutrition (EC 1831/2003) contain special provisions regarding the evaluation of the products used as silage additives (European Commission, 2003). According to the Annex of the Commission's EU 2016/2023 regulation, the minimum and maximum limits of products such as "sodium benzoate, potassium sorbate, formic acid, and sodium formate", which are accepted as additives, were determined according to feed ingredients with a moisture content of $12 \%$. Operational procedures and institutional precautions should be determined for additive and premix users to address the potential risks arising from their use by feed 
operators (European Commission, 2016). In Turkey, only the identification of silage additives is available as per the "Regulation Regarding the Use of Feed Additives Substances in Animal Nutrition" regarding silage. In this document, "silage additives" are defined as "Substances, including enzymes and microorganisms prepared to join the food to improve silage formation." In the 11th article of the regulation, after the approval of a feed additive according to this regulation, the person or other interested parties who use or put in the market a feed in which this additive is used must comply with the conditions or limitations set for placing in the market, use, and storage of the feed additive (DEFRA, 1997). The Ministry carries out inspection and control processes of feed additives-premixes, and statements are included. In the Annex-1 of the same regulation, the category, including "Silage additives" also included the category "Technological feed additives" (Official Gazette, 2013).

In the sixth article of the "Regulation on Feed Hygiene," it was stated that "Feed operators are responsible for the primary production of feeds and their transport, storage, treatment or transport of these feeds to a business or mixing of feeds using no additives or premixes for their animals. They must comply with the conditions stated in Annex-1 regarding their works." (Official Gazette, 2011b).

The definition of $\mathrm{H} 14$ Ecotoxic is included in the Annex 3/A section of the "Waste Management Regulation", which came into force on April 2, 2015, by the Ministry of Environment and Urbanization. $\mathrm{H} 14$ Ecotoxic is defined as "wastes that have sudden or delayed harmful effects on one or more parts of the environment." Moreover, in the waste list coded 02 01, under the heading of "Waste from Agriculture, Gardening, Aquaculture Production, Forestry, Hunting, and Fishing," "plant tissue waste" was included. When the entire regulation was evaluated, it was observed that no provision could be directly related to silage (Official Gazette, 2015).

\section{Discussion}

In UK countries, clear and detailed arrangements have been made at every stage of silage production (silage tanks, their distance to inland waters and coastal waters, additives, storage conditions, etc.) (WAG, 2010). However, due to its various undesirable effects, silage production is not recommended in certain parts of Europe (Wilkinson, 1999). During the conducted survey of the legislation, it was observed that after the enactment of Law No. 5996 in Turkey, various regulations on "feed" came into force; however, there was no specific regulation regarding "silage." It can be suggested that, in terms of human, animal, and environmental health, specific legal regulations should be made on silage, supported by scientific data, which may cause various hazards and is not even recommended for production in certain countries.

The proliferation of $E$. coli in the silo (Driehius et al., 2018) and the presence of molds indicate the entry of air into the silo, implying that the compression and closing operations are not performed appropriately during ensiling (Basmacıoğlu and Ergül, 2002). When silage is used as a feed source on a farm, several events related to increased clostridial spores in silage and milk can occur. While harvesting a silage crop, the crop is inevitably contaminated with soil particles containing clostridial spores (Pahlow et al., 2003). Multiple mycotoxin contaminations in silage are crucial due to their effects on animals (Dell'Orto et al., 2015). In Poland, in 2015, all the tested silage samples from 120 farms were positive for at least one mycotoxin, and $61 \%$ contained five or more mycotoxins simultaneously (Panasiuk et al., 2018). Similarly, Karakaya and Atasever (2010) found that aflatoxin was present in the feed and milk in Pasinler, Erzurum. The authors stated that this situation might cause chronic health problems in humans. Şahindokuyucu et al. (2010) observed various mycotoxin types in corn silage samples in their study in the Burdur province. They reported no requirement of a mandatory analysis of mycotoxins, microbial, or chemical threats, as evidenced by a detailed legislation check. Notably, every aspect of silage has different importance apart from the mycotoxins, which can be found in silage at high concentrations. Therefore, these hazards can occur in silage produced unprofessionally. It should be ensured that farmers and business owners involved in silage production are educated and made aware by relevant professionals to understand the issue's importance. From a legal perspective, regular sampling of silage and mandatory analysis of mycotoxin, microbial, and chemical content can be critical. Therefore, establishing a silage inspection mechanism is essential to establish legal regulations that will ensure planned inspection.

It has been stated that silage additives increase the quality of silage and productivity of animals. For this purpose, various groups of substances are used (Yitbarek and Tamir, 2014). According to the recommendation of the "EU Commission Implementing Regulation" and "European Food Safety Authority (EFSA)" under the proposed conditions of use, sodium benzoate, potassium sorbate, formic acid, and sodium formate have no adverse effects on animal health, human health, or the environment. However, it has also been 
suggested that the respiratory risk of these substances cannot be excluded. Moreover, the risks of additives used and all necessary measures have been specified (EFSA, 2012; EFSA, 2013; EFSA, 2014; EFSA, 2015). While there is abundant information about feed additives in the national legislation, it has been observed that there is no substance and/or provision to deal with silage for the use of mentioned substances. It can be argued that more detailed regulations regarding additives should be created, as in the regulations issued by the EU.

The Department for Environment Food \& Rural Affairs (DEFRA) regulations numbered 1991/324 and $1997 / 547$ state that silage wastes are 100 times more polluting than untreated water. Therefore, care must be taken to minimize the risk of pollution by farmers. It has also been stated that silage causes significant pollution due to insufficient storage capacity or poor storage (DEFRA, 1997). During the production and storage of silage, discharge of silage water into the soil or surrounding water resulting from poor drainage is harmful to the environment (Peterson et al., 1958). Silage wastes equally contribute to environmental pollution outside the growing season or when they spread to the soil during improper weather conditions (WAG, 2010). Furthermore, it has been demonstrated that silage can contain toxins from forage harvesting or various contaminants (Driehuis et al., 2018; Ogunade et al., 2018). Although the definition of "Ecotoxic" is included in the Annex to the "Waste Management Regulation," it is unclear whether the silage water is evaluated within this scope. Therefore, scientific studies and data on this subject should be used to evaluate the damage to the environment by silage and its wastewater, and appropriate measures should be taken accordingly.

Despite the advantages of silage, various problems occur in animal, human, and environmental health during its production and management phase. In order to minimize these problems, scientific methods should be applied at every stage of silage production. Furthermore, specific national regulations regarding silage should be drafted based on EU regulations while giving equal weightage to the damage to human health, animal health, and the environment. Thus, by understanding our responsibility for future generations, scientific studies and data obtained on silage should be evaluated in terms of legislative studies that should be conducted in this direction.

\section{Financial Support}

This research received no grant from any funding agency/sector.

\section{Conflict of Interest}

The authors declare that they have no conflict of interest.

\section{Kaynaklar}

Basmacıoğlu H, Ergül M, 2002: Silage microbiology. J Anim Prod, 43, 12-24.

Boyacı S, Akyüz A, Kükürtcü $M, 2011$ : Büyükbaş hayvan barınaklarında gübrenin yarattığı çevre kirliliği ve çözüm olanakları. Tabad, 4 (1), 49-55.

Çakmak B, Yalçın H, Bilgen H, 2013: Hasıl ve fermente mısır silajlarının ham besin maddesi içeriği ve kalitesine paketleme basıncı ve depolama süresinin etkileri. Tar Bil Der, 19, 22-32.

Department for Environment Food and Rural Affairs (DEFRA), 1997: Control of pollution (silage, slurry and agricultural fuel oil) regulations. Resource Document. Department for Environment Food and Rural Affairs. Accessed; 20.10.2019.

Dell'Orto V, Baldi G, Cheli F, 2015: Mycotoxins in silage: checkpoints for effective management and control. World Myctoxin Journal, 8, 603-617.

Dişbudak K, 2008: Agriculture and environment interaction in Eu and Turkey's harmonization. EU Expertise thesis, Ministry of Agriculture and Rural Affairs Department of External Affairs and EU Coordination, Ankara.

Driehuis F, Wilkinson JM, Jiang Y, Ogunade I, Adesogan AT, 2018: Silage review: Animal and human health risks from silage. J Dairy Sci, 101, 4093-4110.

Eleroğlu H, Yıldız S, Yıldırım A, 2013: The applied methods for removal of poultry feces that creates environmental problem. GBAD, 2, 14-24.

European Commission, 2003: Regulation (EC) No 1831/2003 of the European Parliament and the Council of 22 September 2003 on additives for use in animal nutrition. Official Journal of the European Union, L268/29, 18.10.2003.

European Commission, 2009: Commission Regulation (EC) No 152/2009 of 27 January 2009 laying down the methods of sampling and analysis for the official control of feed. Official Journal of the European Union. L 54/1, 26.2.2009.

European Commission, 2010: Commission Directive 2010/6/EU. amending Annex I to Directive 2002/32/EC of the European Parliament and of the Council as regards mercury, free gossypol, nitrites and Mowrah, Bassia, Madhuca. Official Journal of the European Union, L37/29, 10.02.2010.

European Commission, 2016: Commission Implementing Regulation (EU) 2016/2023. concerning the authorisation of sodium benzoate, potassium sorbate, formic acid and sodium formate as feed additives for all animal species. Official Journal of the European Union. L313/14, 19.11.2016.

European Food Safe Authority (EFSA), 2012: Scientific Opinion on the safety and efficacy of sodium benzoate as a silage additive for pigs, poultry, bovines, ovines, goats, rabbits and horses. EFSA Journal, 10 (7), 2779. 
European Food Safe Authority (EFSA), 2013: Scientific Opinion on the safety and efficacy of potassium sorbate as a silage additive for all animals except dogs and cats. EFSA Journal, 11 (7), 3283.

European Food Safe Authority (EFSA), 2014: Scientific Opinion on the safety and efficacy of formic acid when used as a technological additive for all animal species. EFSA Journal, 12 (10), 3827.

European Food Safe Authority (EFSA), 2015: Scientific Opinion on the safety and efficacy of ammonium formate, calcium formate and sodium formate when used as a technological additive for all animal species. EFSA Journal, 13 (5), 4056.

Görgülü M, 2002: Feeding cattle and small cattle. Çukurova University Faculty 206 of Agriculture Offset Workshop, Adana, Türkiye.

Karakaya Y, Atasever M, 2010: Aflatoxin B1 in corn silage and its probability passing in milk. Kafkas Univ Vet Fak Derg, 16 (Suppl-A), 123-127.

Koçtürk ON, 1975: Ecology and veterinary medicine. Turkish Veterinary Medical Association Central Council Publications, No:13, Ankara, Turkey.

Ministry of Agricultural and Forestry (MAF), 2019: Analysis list. T.C. Ministry of Agriculture and Forestry Central Research Institute of Food and Feed Control.

https://arastirma.tarimorman.gov.tr/bursagida/Belg eler/NKB/2020\%20\%20F\%C4\%BOYAT\%20L\%C4\%BOS TES\%C4\%B0\%20V5.pdf. Date of access; 10.03.2020.

Ministry of Agricultural and Forestry (MAF), 2020: Laboratory analysis fees. T.C. Ministry of Agriculture and Forestry International Center for Livestock Research and Training. https://arastirma.tarimorman.gov.tr/lalahanhmae/ Menu/27/Laboratuvar-Analiz-Ucretleri. Date of access; 10.03.2020.

Official Gazette, 2010: Law No: 5996 on Veterinary services, plant health, food and feed. Official Gazette dated 11.06.2010 and numbered 27610 .

Official Gazette, 2011a: Regulation regarding official control of food and feed. Official Gazette dated 17.12.2011 and numbered 28145.

Official Gazette, 2011b: Regulation on feed hygiene. Official Gazette dated 27.12.2011b and numbered 28155.

Official Gazette, 2013: Regulation regarding the use of feed additives substances in animal nutrition. Official Gazette dated 18.07.2013 and numbered 28711.

Official Gazette, 2014: Communiqué on undesirable substances in feeds. Official Gazette dated 19.04.2014 and numbered 28977.

Official Gazette, 2015: Waste management regulation. Official Gazette dated 02.04.2015 and numbered 29314.

Official Gazette, 2017: (Repeating). Implementing regulation on sampling and analysis methods for official control of feeds. Official Gazette dated 21.01.2017 and numbered 29955.
Ogunade IM, Martinez-Tuppia C, Queiroz OCM, Jiang Y, Drouin P, Wu F, Vyas, D, Adesogan AT, 2018: Silage review: Mycotoxins in silage: Occurrence, effects, prevention, and mitigation. J Dairy Sci, 101 (5), 4034-4059.

Özhan M, 2010: SILAGE (Silo Feed) preparation, use and value. Atatürk Univ J Agricultural Faculty, 6, 51-61.

Pahlow G, Muck RE, Driehuis F, Oude Elfrink SJWH, Spoelstra SF, 2003: Microbiology of ensiling. In: L. Al-Amoodi (Ed.), 31-93. Silage science and technology. Wisconsin, USA.

Panasiuk L, Jedziniak P, Pietruszka K, Piatkowska P, Bocian $L$, 2018: Frequency and levels of regulated and emerging mycotoxins in silage in Poland. Mycotoxin Res, 35, 17-25.

Peterson W, Burris RH, Sant R, Little HN, 1958: Toxic gases in silage, production of toxic gas (nitrogen oxides) in silage making. J. Agric. Food Chem., 6, 121-126.

Peypazar ZB, Kılıç I, 2021: Evaluation of waste management systems in dairy cattle farms in terms of environmental pollution: Kütahya case study. Uludağ Univ. J. Fac. Eng., 26 (1), 15-28.

Şahin IF, Zaman M, 2010: An Important Cattle Feed: SILAGE. Eastern Geographical Review, 15, 1-18.

Şahindokuyucu F, Mor F, Oğuz MN, Karakaş Oğuz F, 2010: Investigation of mycotoxins occurrence and levels in silages samples collected in Burdur province. Uludag Univ. J. Fac. Vet. Med., 29, 49-54.

Tırınk S, 2021: Environmental effects and diffuse pollution load calculation of animal wastes in lğdır province and districts. BSJ Eng Sci, 4 (2), 43-50.

Uygur MA, 2005: What is Silage? Its History, Importance, Benefits and Silage Making Stages. T.C. Ministry of Agriculture and Rural Affairs, General Directorate of Agricultural Research, Aegean Agricultural Research Institute, Farmer Brochure, İzmir, Turkey.

Ünder H, 1996: Çevre felsefesi: etik ve metafizik görüşler. Doruk Yayımcilık, Ankara.

Welsh Assembly Government (WAG), 2010: The water resources (control of pollution) (silage, slurry and agriculture fuel oil) (wales) regulations. Welsh Assembly Government dated 18 June 2010 and numbred 1493 (W.136).

Wilkinson JM, 1999: Silage and animal health. Natural Toxins, 7, 221-232.

Yaylak E, Alçiçek A, 2003: A cheap forage source for the fattening of beef cattle: corn silage. Hayvansal Üretim, 44 (2), 29-36.

Yıldııım A, Şimşek H, 2013: Sosyal bilimlerde nitel araştırma yöntemleri. Genişletilmiş 9. Baskı. Seçkin/Sosyal Bilimler, Ankara.

Yitbarek MB, Tamir B, 2014: Silage additives. Open J. Appl. Sci, 4, 258-274.

${ }^{*}$ Yazışma Adresi: Gökhan ASLIM

Selçuk Üniversitesi, Veteriner Fakültesi, Veteriner Hekimliği Tarihi ve Deontoloji AD, Konya, Türkiye.

e-mail: gokhan.aslim@selcuk.edu.tr 